\title{
反回神経損傷後の疑核における塩基性線維芽細胞増殖因子の発現
}

\author{
讃 岐 徹 治 ${ }^{1)}$ ・湯 本 英 二 ${ }^{2)}$. 兵 頭 政 光 ${ }^{1)} \cdot$ 河 北 誠 二 ${ }^{1)}$ \\ 小 森 正 博 ${ }^{1)} \cdot$ 本 吉 和 美 ${ }^{1)}$
}

\section{Expression of Basic Fibroblast Growth Factor in the Nucleus Ambiguus in Rats following Unilateral Recurrent Laryngeal Nerve Injury}

\author{
Tetsuji Sanuki ${ }^{1)}$, Eiji Yumoto ${ }^{2)}$, Masamitsu Hyodo ${ }^{1)}$, \\ Seiji Kawakita ${ }^{1)}$, Masahiro Komori ${ }^{1)}$ and Kazumi Motoyoshi ${ }^{1)}$
}

Basic fibroblast growth factor (bFGF), which is a member of fibroblast growth factor family, has been demonstrated to play important roles in neural development and regeneration. In this study, we investigated the expression pattern of bFGF in the rat nucleus ambiguus (NA) following unilateral recurrent laryngeal nerve (RLN) injury and discussed the roles of bFGF on neural regeneration.

This study involved thirty-three rat subjects. In the first group $(n=15)$, the left RLN was crushed with forceps at the location of the seventh tracheal ring. In the second group $(n=15)$, the left RLN was resected for $5 \mathrm{~mm}$ in length. The brainstems of rats were excised on the 1st, 3rd, $7 \mathrm{th}$, 14 th and 28th days after the procedure in both groups. In the normal group $(n=3)$, rats served as controls. The brainstems were rapidly frozen and $20 \mu \mathrm{m}$-thick serial sections were cut on a cryostat. The sections were processed for immunohistochemical staining using anti-bFGF antibody. The expression of bFGF in the NA was quantitatively evaluated via an image analysis technique.

Although a weak expression of bFGF in the NA was identified in the normal group, the expression had increased in the crushed and resected groups. In particular, bFGF was expressed up to 7 times as much as in the untreated side on the 14th day following RLN resection.

These findings suggest that the expression of bFGF in the NA is promoted by RLN injury and that it is deeply associated with a regeneration of the injured nerve by preventing lesion-induced neural death.

Key words：疑核，塩基性線維芽細胞増殖因子，反回神経，神経再生

$$
\text { は じめに }
$$

近年，神経損傷時に種々の神経栄養因子が神経損傷部の みならず神経核においても発現することが明らかにされ， 神経再生過程における神経栄養因子の関与が注目されてい る112)．われわれは神経栄養因子が反回神経脱神経後の神経 再生に及ぼす効果について, 神経成長因子 (nerve growth factor)，毛様体神経栄養因子（ciliary neurotrophic factor)，塩基性線維芽細胞増殖因子（basic fibroblast growth factor，以下 bFGF) を反回神経切断端間に局所 投与することにより検討した。その結果，これら 3 種類の 神経栄養因子の中では bFGF が神経再生に最も促進的に 作用することを報告した ${ }^{3)}$. しかしこの研究は神経栄養因 子の作用効果を反回神経損傷部で検討したものであり，神 経再生過程において重要な要因の一つである神経核，すな
わち疑核の機能維持に対する神経栄養因子の効果は未だ明 らかになっていない. そこで今回, 神経切断部で反回神経 再生に最も促進的に作用した bFGF の, 反回神経脱神経 後の疑核神経細胞における発現様式を免疫組織学的に検討 した。 その結果と bFGF発現の意義について考察を加え て報告する。

$$
\text { 方法 }
$$

実験には生後11〜12週齢の Wistar 系雄性ラット33匹を 用い，愛媛大学医学部動物実験指針に従って行った。

動物は圧迫群と切断群（各15匹）および前処置を加えな い正常群 ( 3 匹) の 3 群に分けた. 圧迫群と切断群はペン トバルビタール腹腔内投与 $(30 \mathrm{mg} / \mathrm{kg})$ にて全身麻酔後, 前頸部を正中切開して手術用顕微鏡下に左反回神経を慎重 に露出した．同神経を喉頭への進入部より $10 \mathrm{~mm}$ 中枢側

1 ) 愛媛大学医学部耳鼻咽喉科学教室

2 ) 熊本大学医学部耳鼻咽喉科学教室

1 ) Department of Otolaryngology, Ehime University School of Medicine, Ehime

2 ) Department of Otolaryngology - Head and Neck Surgery, Kumamoto University School of Medicine, Kumamoto 
で以下の 2 通りの方法で前処置した. (1)圧迫群：2.0kg/ $\mathrm{cm}^{2}$ 圧，持針部の幅 $1 \mathrm{~mm}$ のマイクロサージャリー用持針 器により神経を 5 秒間圧迫した. (2)切断群：反回神経を中 枢側に向かって $5 \mathrm{~mm}$ 切除し, 神経断端には特に処置を 加えなかった.

正常群の 3 匹と, 圧迫群および切断群では処置後それぞ れ 1，3，7，14，28日の各 3 匹ずつを前述と同様の方法 で全身麻酔した後, 生理食塩水にて経心的に灌流し, さら

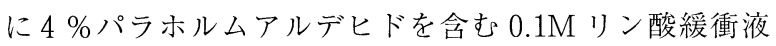
(0.1M PBS, pH 7.4) で灌流固定した。その後, 開頭し て脳幹を摘出し, 同灌流液中に 5 分間浸漬して後固定した。 ついで脳幹を液体窒素で羚却したイソペンタン内で急速凍 結し, クライオスタットを用いて, 反回神経の運動神経核 である疑核神経細胞が含まれる舌下神経核吻側から下オリー ブ核尾側まで, $20 \mu \mathrm{m}$ 厚の連続切片を作成した。
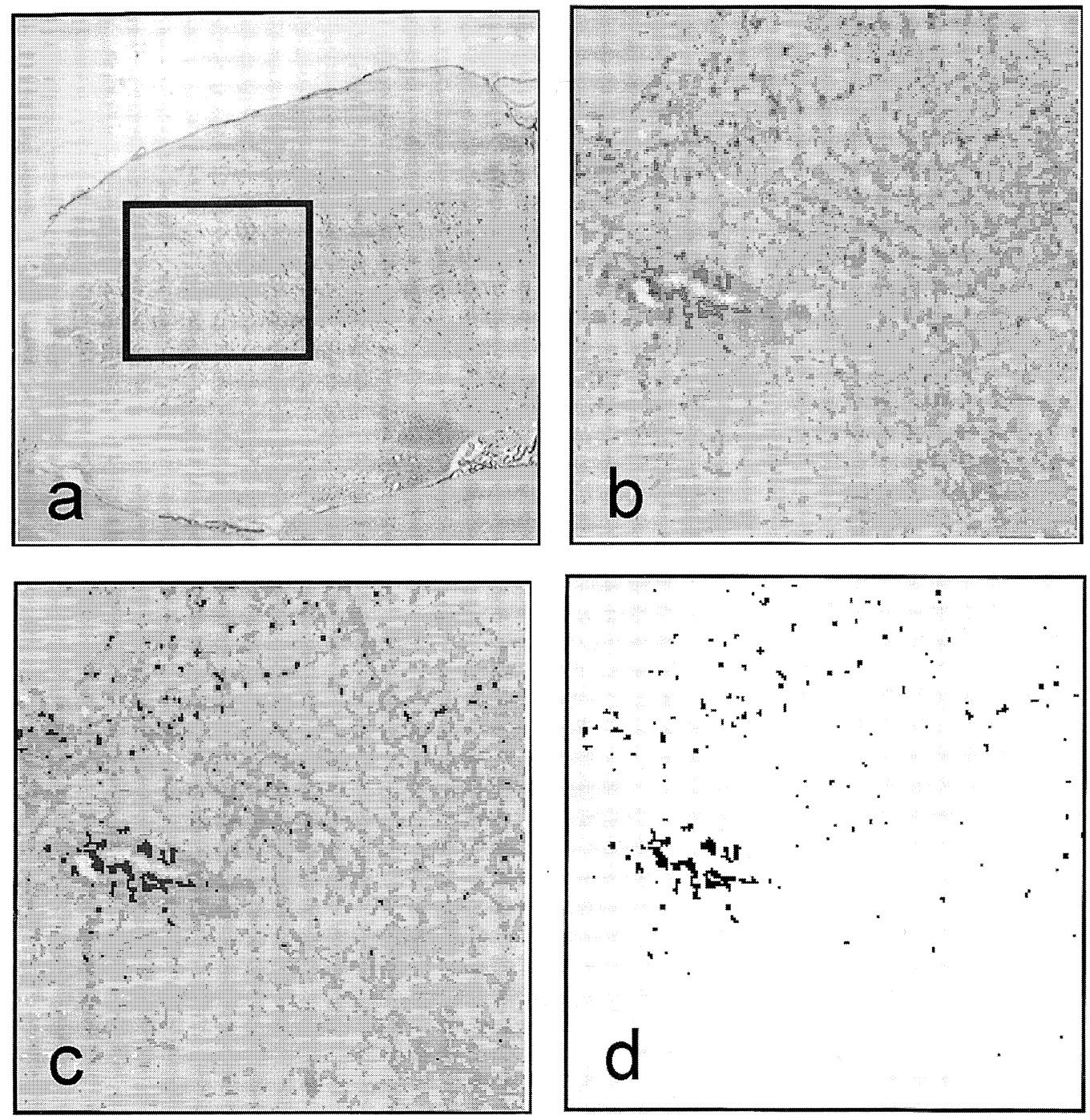

図 1 画像処理による bFGF 発現の定量的比較法

$\mathrm{a}$ ：光顕像を CCD カメラを通してコンピューターに取り込み，疑核神経細胞を含む領域を選択する.

$\mathrm{b}$ ：選択範囲の画像をグレースケール256階調に変換する.

c：閾値を設定し, 免疫染色陽性部分を抽出する.

$\mathrm{d}$ ：白黒 2 階調に画像を変換して, 疑核の免疫染色陽性部分の画素数を計測する.

\section{1. 免疫組織学的検討}

作成した切片は Labeled Streptavidine Biotin 法を用 いて bFGFの免疫染色を行った。まず $0.25 \%$ カラゲニン， $5 \%$ \%シ血清アルブミン加 $0.1 \mathrm{MPBS}$ で 1 時間処理し, 内 因性ペルオキシダーゼを失活させた. 次いで正常ウシ血清 アルブミンを加えた後, 1 次抗体（抗 bFGF 抗体, 250倍 希釈）を45分間反応させた.ささらに 2 次抗体（ビオチン標 識抗マウス $\operatorname{IgG}$ ・ウサギ抗体，500倍希釈）を30分間反応 させた後, ペルオキシダーゼ標識ストレプトアビジンにて 処理し, ジアミノベンチジンにて発色させた. 標本は光学 顕微鏡（以下，光顕）にて観察した。なお疑核の同定には ラット脳アトラス ${ }^{4)}$ を参考にした。

\section{2. bFGF 発現の定量的評価}

光顕の組織像を鏡筒上に設置した CCD カメラ（富士写 真フイルム社, FUJIX HC-300）を通してパーソナルコン

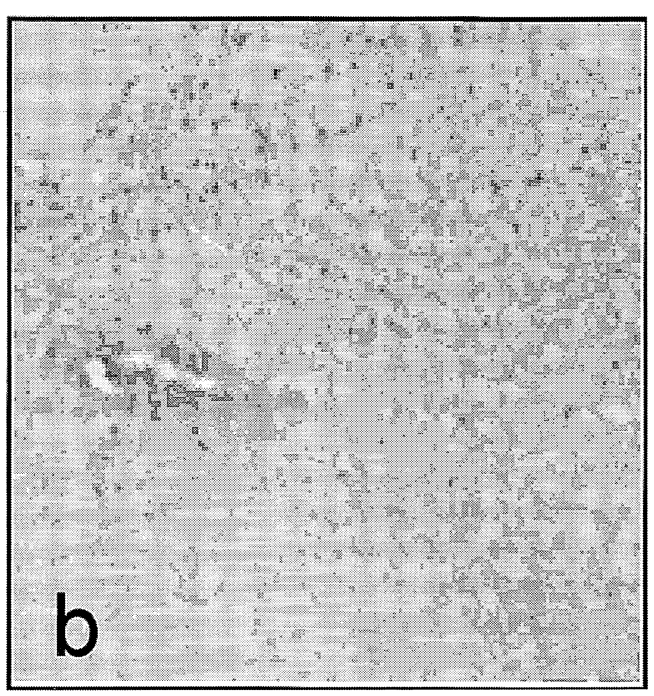


ピューター (Apple社, Power Macintosh 7600/132) に 取り込んた（図 1 a ). 処置側および非処置側の疑核を画 像解析ソフト（NIH image）を用いて以下の方法で画像 処理し, bFGF発現量を定量的に比較した。まず疑核を含 む矩形領域のグレースケール256階調の画像（図 1 b ）を 免疫反応陽性部分が抽出されるように閾值設定（図 1 c ） した後, 白黒 2 階調に画像を変換した（図 $1 d$ ）。この画 像より, 疑核における bFGF 陽性の神経細胞の面積, す なわちピクセル画素数を計測した ${ }^{5) 6}$. 各脳幹ごとに連続 切片の 1 枚おきにこの計測を行い, 反回神経を支配する疑 核が存在する範囲に相当する計40枚の切片での計測值を処 置側, 非処置側ごとに合計した. 脳幹ごとの合計值を処置 側 (左側：L) と非処置側 (右側：R）と比較 ( $\mathrm{L} / \mathrm{R}$ 比) することにより, bFGF 発現量を定量化し, 処置後の経過 日数ごとに発現量の変化を検討した。なお今回は, 各処置 後日数ごとの検討数が 3 匹と少ないため, 統計学的検討は 行わなかった。

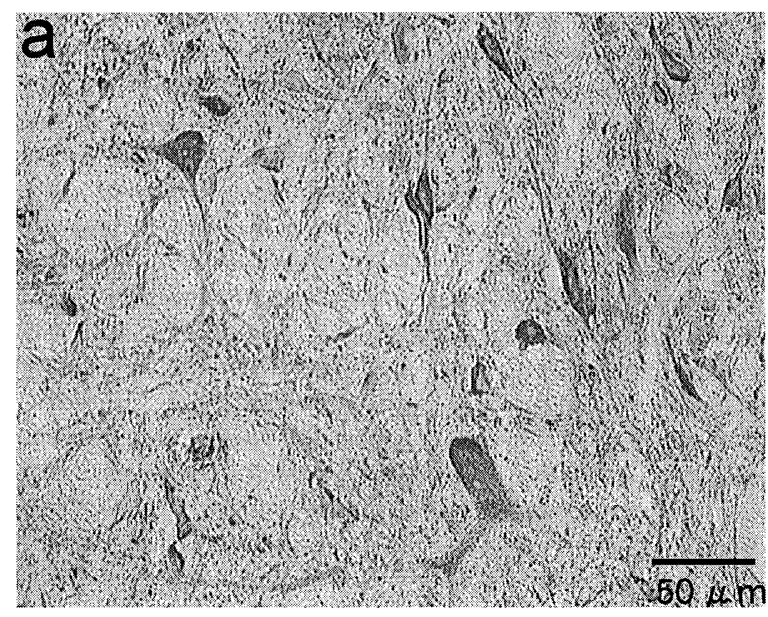

結 果

\section{1. 免疫組織学的検討}

正常群の疑核神経細胞も軽度ながら褐色に染色され bFGF の存在が確認できた. 圧迫群では処置の 1 日後には, 処置側と非処置側との間で神経細胞の染色性に明らかな差 を認めなかったが，3 日後では処置側の神経細胞がわずか に濃く染色され，7日後では非処置側との差がより明らか となった（図 2 ). しかし14日後および28日後には, 両者 間でほとんど差が見られなかった。

一方, 切断群では処置の 1 日後以降処置側が非処置側に 比べて濃く染色され，14日後に最も強い染色性を示した (図 3 ). 28日後には処置側の染色性は14日後に比べ減弱し たが, 非処置側よりはやや強かった.

\section{2. bFGF 発現の定量的評価}

正常群では bFGF 発現に明らかな左右差は認めなかっ た（L/R 比：101\%). 圧迫群では処置の 1，3 日後では,

図 2 圧迫群の疑核神経細胞に扮ける bFGF 免疫染色結果

$\mathrm{a}$ ：処置側（処置後 7 日） bFGF が神経細胞の細胞質内に強く発現している.

$\mathrm{b}$ : 非処置側（処置後 7 日） bFGF 発現は, 処置側に比べて弱い.
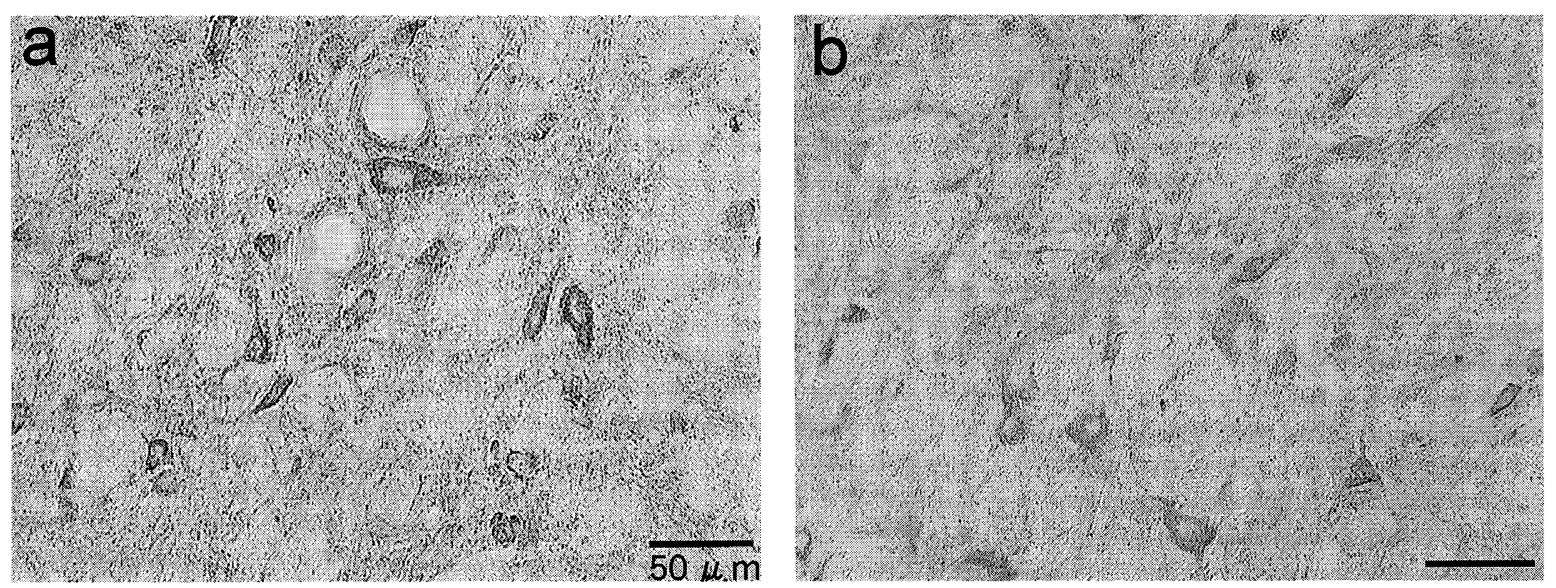

図 3 切断群の疑核神経細胞における bFGF 免疫染色結果

$a ：$ 処置側（処置後14日） bFGF が神経細胞の細胞質内に強く発現している.

$b$ ：非処置側（処置後14日） bFGF 発現は，処置側に比べて弱い. 


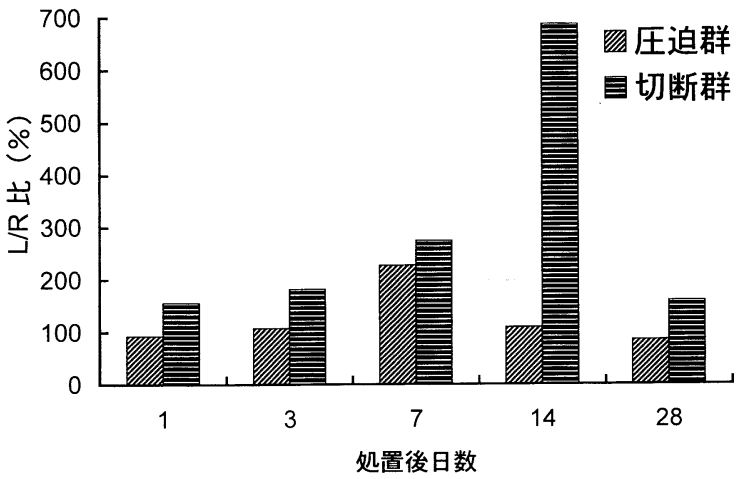

図 4 圧迫群と切断群に扔ける $\mathrm{bFGF}$ 発現量（平均値） の定量的比較

圧迫群では処置の 7 日後に非処置側の $225 \%$ に増加 するが，1，3，14，28日後は増加がみられない． 一方，切断群ではすべての時期で非処置側に比べ増 加した. 発現のピークは14日後にあり, 発現量も压 迫群に比べ多い.

$\mathrm{L} / \mathrm{R}$ 比が98\%および107\%で処置側と非処置側との間の bFGF 発現にほとんど差がなかったが，7日後には225\% に増加した。 14，28日後には，それぞれ109\%および85\% であり, 処置側と非処置側との間に差は見られなかった。

切断群では，1日後ですでに L/R 比が $156 \%$ と処置側の bFGF 発現が増加していた。 その後も $\mathrm{L} / \mathrm{R}$ 比は増加を続 け，14日後には最大の685\%に達した。28日後には14日後 に比べ L/R 比は減少したが, 160\%と依然として高值であっ た（図 4 ）。

$$
\text { 考察 }
$$

bFGFはこれまでに 9 種類が確認されている線維芽細 胞増殖因子 (fibroblast growth factor) 群の一つであ る. bFGF は正常の神経細胞内にも存在 ${ }^{7)}$, 中胚葉系組 織の形成や四肢形成などへの関与, 神経再生に対する作用 などがあるとされている ${ }^{8)}$ 10) . 神経損傷後には神経損傷 部および神経細胞において発現量が増加することも報告さ れている(1)211). しかし, 反回神経脱神経後の bFGF 発現 動態は未だ解明されておらず，特に運動神経核である疑核 での検討はなされていない.

今回われわれは, 一側反回神経脱神経後の疑核神経細胞 における bFGF 発現を免疫組織学的に検討し, さらにそ の結果を画像処理的手法を用いて, 非処置側と定量的に比 較した. 本法は Mize ら ${ }^{5)}$ が報告した手法で, 組織の観察 と定量的検討を同一標本上で比較的簡便に行うことができ, 疑核のように神経細胞が散在性に存在する場合には, 特に 有効な解析方法であると考える。

今回の検討において反回神経に損傷を加えることにより， 疑核での bFGF 発現量は圧迫群および切断群ともに非処 置側に比べて増加した。また，圧迫群と切断群を比較する と, より強い神経損傷と考えられる切断群は圧迫群に比べ て bFGFの発現が早期より増加し, 増加した期間も長かっ
た. また発現量も切断群の方が圧迫群に比べて大きかった.

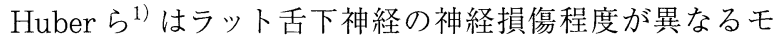
デルを用いて, bFGF 発現の経時的変化を検討した。その 結果, 神経挫滅では 3 日目に舌下神経核の bFGF 発現量 が最も増加し，16日目には非処置側と同じレベルに戻った. 神経切断では11日目に発現量が最も増加し，28日目でも非 処置側より高值であった。また舌下神経損傷後，損傷部位 においても神経細胞と同様に bFGF 発現の経時的変化が 認められたとも報告した1). 彼らの研究や本研究により, 疑核や舌下神経核などの運動神経細胞では神経末梢部の損 傷後の神経再生過程において bFGF 発現が増加すること が明らかとなった。 bFGF 発現増加の機序としては, (1) bFGFは, 神経組織に広く存在するとされており ${ }^{7) 11)}$, 神 経損傷部より遊離された多量の bFGF が損傷部位中枢端 より取り込まれ，逆行性軸索輸送により神経核に達した

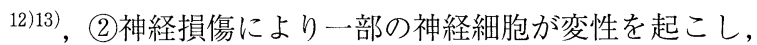
その結果放出された bFGFが神経核に取り込まれるか, もしくは結合することにより神経細胞における bFGFが 増加した ${ }^{14) 15)}$ などの可能性が考えられる. しかし，この点 に関しては未だ推測の域を出ず，今後の検討が必要である と考える.

Huber $ら^{1)}$ は舌下神経核で増加した bFGF は神経再生 に関与するタンパク質の増加を促し，神経損傷により引き 起こされる神経細胞死を防止していると報告した。また小 森 ${ }^{3)}$ は，神経損傷部に bFGF を投与することにより，損 傷部位での神経再生が促進されるとともに，疑核において も神経細胞の萎縮防止効果があったと報告した。このよう なことから，神経核で発現した bFGFは，神経損傷によ り引き起こされる神経細胞の萎縮や変性を防止する効果が あるものと考えられる。すなわち, bFGFなどの神経栄養 因子は神経末梢の損傷部のみならず，神経細胞においても 神経再生にとって重要な機能を担っていると結論づけられ る。さらに，神経切断と圧迫という神経損傷程度の違いに より，運動神経核での bFGF 発現量に違いがあることは， bFGF 発現に関与する一種の自己調節機構が存在してい ることも示唆された。

\section{ま と め}

一側反回神経脱神経後の疑核神経細胞における bFGF 発現様式を免疫組織学的に観察し, さらに画像処理的手法 により非処置側と定量的に比較した。

圧迫群では処置の $1 \sim 3$ 日後では bFGF 発現量に変化 がなく, 7 日後に非処置側と比較して増加した。一方，切 断群では, 処置の 1 日後より bFGF 発現量が増加し14日 後に最大となり，その後も発現増加が持続した。また $\mathrm{bFGF}$ 発現の増加率も，圧迫群に比べて大きかった。この 違いは神経損傷程度の違いに基づくものと考えられ， bFGFなどの神経栄養因子が神経細胞の機能維持に深く 関与していることが示唆された。 
本論文の要旨は, 第11回日本喉頭科学会 (平成11年 3 月, 広島市）において口演した。

\section{参 考 文 献}

1) Huber $\mathrm{K}$ et al : Expression of fibroblast growth factor-2 in hypogrossal motoneurons is stimulated by peripheral nerve injury. J Comp Neurol 382: 189 198, 1997.

2) Grothe $\mathrm{C}$ et al : Expression of fibroblast growth factor-2 and fibroblast growth factor receptor 1 messenger RNAs in spinal ganglia and sciatic nerve: regulation after peripheral nerve lesion. Neuroscience $76: 123 \sim 135,1997$.

3）小森正博: 反回神経再生に対する神経栄養因子の効 果. 耳鼻臨床 92：677〜686, 1999.

4) Palkovits $M$ \& Brownstein $\mathrm{MJ}:$ Map and guide to microdissection of the rat brain, $81 \sim 207$, Elsevier, New York, 1988.

5) Mize RR : Quantitative image analysis for immunocytochemistry and in situ hybridization. J Neurosci Methods 54:219 237, 1994.

6) Toyokuni $S$ et al : Quantitative immunohistochemical determination of 8-hydroxy-2'deoxyguanosine by a monoclonal antibody N45.1: Its application to ferric nitrilotriacetateinduced renal carcinogenesis model. Lab Invest $76: 365 \sim 374,1997$.

7) Matsuyama A et al : Localization of basic fibroblast growth factor-like immunoreactivity in the rat brain. Brain Res 587: 49 65, 1992.

8) Grothe $\mathrm{C}$ et al : Basic FGF-like immunoreactivity in the developing and adult rat brainstem. J Comp Neurol 305: 328 336, 1991.

9) Korsching $\mathrm{S}:$ The neurotrophic factor concept: a reexamination. J Neurosci $13: 2739 \sim 2748$, 1993.

10) Chen YS et al : Effects of basic fibroblast growth factor (bFGF)-neutralizing antibody and platelet factor 4 on facial nerve regeneration. Exp Neurol 155:274 283, 1999.

11) Grothe C \& Wewetzer K : Fibroblast growth factor and its implications for development and regeneration neurons. Int $J$ Dev Biol 40 : 403 410, 1996.

12) Grothe C \& Unsicker K : Basic fibroblast growth factor in the hypoglossal system: specific retrograde transport, trophic, and lesionrelated responses. J Neurosci Res $32: 317 \sim 328$, 1992.

13) Grothe $C$ \& Janet $T$ : Expression of FGF-2 and FGF receptor type 1 in the adult rat brainstem: effect of colchicine. J Comp Neurol 353: 18 24, 1995.

14) Yoshida $\mathrm{K}$ \& Gage $\mathrm{FH}:$ Fibroblast grow th factors stimulate nerve growth factor synthesis and secretion by astrocytes. Brain Res 538 : 118 126, 1991.

15) Cornelio GC et al : Fibroblast growth factor (FGF) levels in the developing rat brain. Dev Brain Res $52: 241 \sim 246,1990$.

別刷請求先 =791-0295 愛媛県温泉郡重信町大字志津川 愛媛大学医学部耳鼻咽喉科学教室 讃岐徹治 